\title{
Statistics on the accuracy of the geographic north calculation as a function of solar ecliptic parameters
}

\author{
Natacha Oliveira Santos ${ }^{1}$, Cosme F. Ponte-Neto ${ }^{2}$, André Wiermann ${ }^{2}$ \\ ${ }^{1}$ Universidade Federal Fluminense - Instituto de Geociências \\ ${ }^{2}$ Observatório Nacional - ON/MCTIC - Departamento de Geofísica - Laboratório de Desenvolvimento de Sensores \\ Magnéticos (LDSM)
}

Copyright 2019, SBGf - Sociedade Brasileira de Geofísica

This paper was prepared for presentation during the $16^{\text {th }}$ International Congress of the Brazilian Geophysical Society held in Rio de Janeiro, Brazil, 19-22 August 2019.

Contents of this paper were reviewed by the Technical Committee of the $16^{\text {th }}$ International Congress of the Brazilian Geophysical Society and do not necessarily represent any position of the SBGf, its officers or members. Electronic reproduction or storage of any part of this paper for commercial purposes without the written consent of the Brazilian Geophysical Society is prohibited.

\section{Abstract}

The present work aims the study of the uncertainties of functions that determine the solar azimuth and solar height, having the purpose the construction of a geophysical device for the automatic determination of the true North based on astronomical parameters.

\section{Introduction}

The determination of True North has great importance for several areas of knowledge, such as: geomagnetism, applied geophysics, cartography and navigation.

In geophysics context, it is of particular importance to determine the magnetic declination, a parameter directly related to the study of geomagnetic secular variation. The magnetic declination varies point to point on the surface of the Earth and varies over time at different rates at different locations. All these characteristics contribute to complexity of determining the magnetic declination, which requires the true north to be determined with a wellestablished methodology.

This study is the first stage of development of a device, that will automatically estimate the true north direction based on local time, geographical coordinates and the solar apparent position. Therefore, it is necessary to evaluate the astronomical problem, examining the uncertainties in the function to calculate the solar azimuth and the height of the sun.

The study of errors in the astronomical equations was done through of computational simulations, creating a data set of 200 synthetic variations for different scenarios, analyzing the uncertainties propagation that the variables generate in the result, individually and combined.

\section{Method}

For the calculation of true North, we will base on the study of position astronomy, specifically on apparent motion of the Sun. Thus, we will use a coordinate system called the
Local Horizontal System to describe the position of the Sun.

This is a fixed reference system on Earth, in which the observer $(\mathrm{O})$ occupies its center (see figure 1).

In this reference system, the position of the star is determined by two coordinates, the height (h) and the azimuth $(A)$, the observer stays at point $O$, the points $N$, S, L, and W correspond to North, South, East and West, respectively.

The height $(\mathrm{h})$ corresponds to the angle measured in the vertical plane between the horizontal direction and the direction in which the star is seen by the observer. The height varies in range: $-90^{\circ}<\mathrm{h}<90^{\circ}$, being agreed that $\mathrm{h}$ is positive above horizon, when the star is visible, and negative below horizon, when the star is not visible.

The azimuth $(A)$ is the angle measured in the horizontal plane, clockwise, between the north direction and the vertical half-plane that contains the star, the azimuth varies in the interval: $0<A<360^{\circ}$.

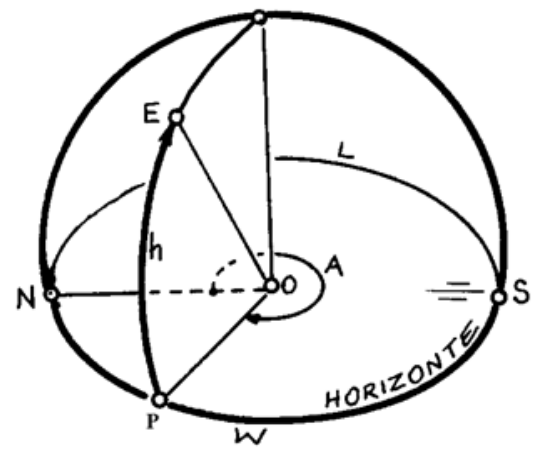

Figure 1 - Local Horizontal System: (h)-height; (A)-azimuth; (E)star; (O) - observer, (N, S, L, W) - north, south, east, west.

The simplest way to determine True North is to observe the vertical stem shade perched on a horizontal plane for an entire day. At the instant the shadow is smaller, i.e. the Sun is at its maximum height, and the line segment that connects the end of the shadow with the base of the stem will be in the True North's direction. (Boczko, Roberto, 1988. Concepts of Astronomy).

However, we intend to determine the True North observing the Sun at a single instant of the day, a procedure simpler from observational point of view than observing the Sun during all day. On the other hand, it involves relatively complex mathematical calculations and much accuracy in determination of the Sun's coordinates and the moment of observation. 
A computer program was implemented to provide the Sun's Height and Azimuth as Latitude, Longitude and Local Time Zone functions.

$$
\begin{aligned}
& \mathrm{A}=f 1 \text { (Lat, Long, UTC) } \\
& \mathrm{h}=f 2 \text { (Lat, Long, UTC) }
\end{aligned}
$$

Through these two functions was possible to determine the direction of the True North, as shown in figure 1.

The first step was to study the propagation of errors in the calculation of the azimuth and the height of the sun using a statistical method based on computational simulations with noise contaminated parameters, which resulted in histograms of 200 data sets where it is possible to evaluate the errors propagated through the functions.

The study was done in two different hours: $6 \mathrm{~h}$ and $12 \mathrm{~h}$, to verify the different errors at different times. We contaminate the measurements with Gaussian errors, where for latitude and longitude were used a variation of 100 meters and for the time, 20 seconds. These errors are highly conservative, as they're far greater that an ordinary GPS can provide.

\section{Results}

To visualize the simulations results, histograms were made to show how azimuth and height errors are distributed when we contaminate Latitude, Longitude, and Time1 (6hrs) and Time2 (12hrs). The data presented are: the expected azimuth and height, the simulated mean and standard deviation of the simulation.

To these simulations we used the latitude of $-22.90^{\circ}$ and the longitude of $-43.21^{\circ}$, referring to the locality of the Observatório Nacional, in the city of Rio de Janeiro.

Table1- Error results table for the simulation of the azimuth calculation

\begin{tabular}{|c|c|c|c|}
\hline & $\begin{array}{c}\text { Expected } \\
\text { azimuth }\end{array}$ & $\begin{array}{c}\text { Mean of the } \\
\text { simulation }\end{array}$ & $\begin{array}{c}\text { Standard } \\
\text { deviation }\end{array}$ \\
\hline $\begin{array}{c}\text { Contaminated } \\
\text { latitude }\end{array}$ & $8.77^{\circ} \times 10^{1}$ & $8.77^{\circ} \times 10^{1}$ & $4.66^{\circ} \times 10^{-5}$ \\
\hline $\begin{array}{c}\text { Contaminated } \\
\text { longitude }\end{array}$ & $8.77^{\circ} \times 10^{1}$ & $8.77^{\circ} \times 10^{1}$ & $3.65^{\circ} \times 10^{-4}$ \\
\hline $\begin{array}{c}\text { Contaminated } \\
\text { Time1 }\end{array}$ & $8.77^{\circ} \times 10^{1}$ & $8.77^{\circ} \times 10^{1}$ & $3.28^{\circ} \times 10^{-2}$ \\
\hline $\begin{array}{c}\text { Contaminated } \\
\text { Time2 }\end{array}$ & $3.52^{\circ} \times 10^{2}$ & $3.52^{\circ} \times 10^{2}$ & $2.24^{\circ} \times 10^{-1}$ \\
\hline $\begin{array}{c}\text { Contaminated } \\
\text { all the variables }\end{array}$ & $8.77^{\circ} \times 10^{1}$ & $8.77^{\circ} \times 10^{1}$ & $3.27^{\circ} \times 10^{-2}$ \\
\hline
\end{tabular}

Frequency x Azimuth $\left(^{\circ}\right)$

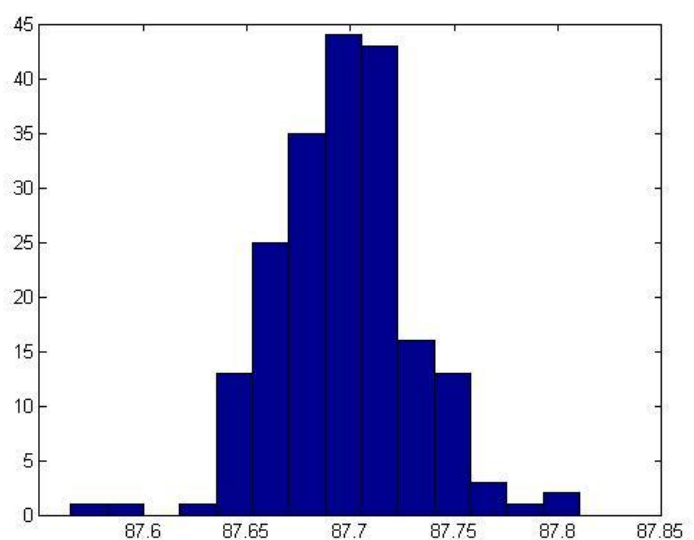

Figure 2 - Histogram of azimuth values related to contamination of all variables

Table 2- Error results table for the simulation of the height calculation

\begin{tabular}{|c|c|c|c|}
\hline & $\begin{array}{c}\text { Expected } \\
\text { height }\end{array}$ & $\begin{array}{c}\text { Mean of the } \\
\text { simulation }\end{array}$ & $\begin{array}{c}\text { Standard } \\
\text { deviation }\end{array}$ \\
\hline $\begin{array}{c}\text { Contaminated } \\
\text { latitude }\end{array}$ & $2.74^{\circ}$ & $2.74^{\circ}$ & $3.91 \times 10^{-5}$ \\
\hline $\begin{array}{c}\text { Contaminated } \\
\text { longitude }\end{array}$ & $2.74^{\circ}$ & $2.74^{\circ}$ & $8.58^{\circ} \times 10^{-4}$ \\
\hline $\begin{array}{c}\text { Contaminated } \\
\text { Time1 }\end{array}$ & $2.74^{\circ}$ & $2.75^{\circ}$ & $7.74^{\circ} \times 10^{-2}$ \\
\hline $\begin{array}{c}\text { Contaminated } \\
\text { Time2 }\end{array}$ & $6.59^{\circ} \times 10^{1}$ & $6.59^{\circ} \times 10^{1}$ & $1.24^{\circ} \times 10^{-2}$ \\
\hline $\begin{array}{c}\text { Contaminated } \\
\text { all the } \\
\text { variables }\end{array}$ & $2.74^{\circ}$ & $2.75^{\circ}$ & $7.72^{\circ} \times 10^{-2}$ \\
\hline
\end{tabular}

Frequency $\times$ Height $(\stackrel{\circ}{)}$

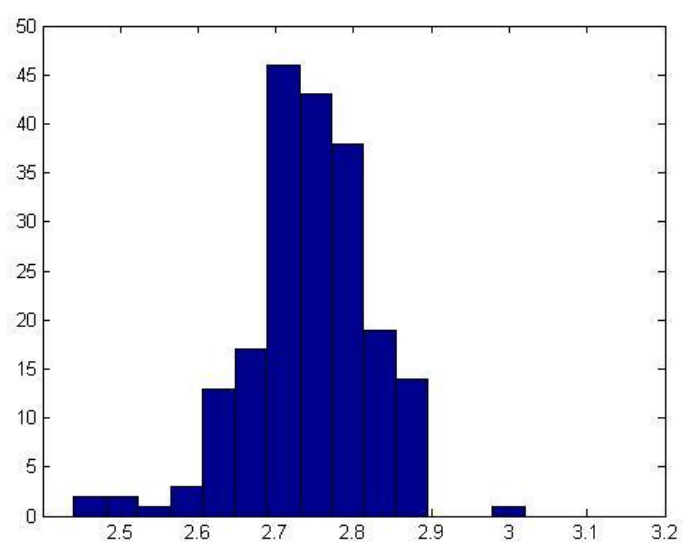

Figure 3 - Histogram of height values related to contamination of all variables

\section{Conclusions}

Observing the propagated errors of the azimuth and the height we see that the results are satisfactory and are distributed in Gaussian form, as the input data. The function errors are minimal, especially considering the exaggerated errors that were applied in the simulation. 
These results shows that the only limiting factor to use astronomical functions and GPS data to estimate automatically the True North is the solar azimuth determination, a process depending on electronic sensors and optical arrangements.

\section{Next steps}

A special hardware to implement the functions here evaluated is under development. This device will embed, beside the astronomical functions, a GPS antenna and will be used to estimate the True North semi automatically in real time in the field.

\section{Acknowledgments}

Observatório Nacional - ON/MCTIC - Departamento de Geofísica - Laboratório de Desenvolvimento de Sensores Magnéticos (LDSM).

The first author thanks CNPq for the scholarship grant that supports this work.

\section{References}

BARRETO, L. M., Astronomia Geral. Publicações do Observatório Nacional. Rio de Janeiro. 1984.

CLEMENCE, G.M. and WOOLARD. E. W., Spherical Astronomy. Academic Press. New York. 1966.

DOMINGUES, F. A. A. Astronomia de Posição. Escola Politécnica. Universidade de São Paulo USP. São Paulo. 1986.

LANG, K., Astrophysical Formulae: a compendium for the physicist and astrophysicist, Springer Verlag. Berlim. 1990.

ANDERSON, J.M \& MIKHAIL, E.M., Surveying Theory and Practice. 7th Edition. Ed. McGraw-Hill. USA. 1998.

CORRÊA, I.C.S., Topografia Aplicada a Engenharia Civil. Departamento de Geodésia, Instituto de Geociências / UFRGS. 2010.

SCHERZ P. and MONK S., Practical Electronics for Inventors, 3rd Edition. McGraw-Hill. USA.2013.

BOCKZO, Roberto, 1988. Conceitos de Astronomia. Editora Edgard Blücher Ltda. São Paulo.

NUSSENZVEIG, Herch Moisés, 1981. Curso de Física Básica, Volume 1-Mecânica. Editora Edgard Blücher Ltda. São Paulo

MOURÃO, R. R. F., 1986. Atlas Celeste. Editora Vozes Ltda. Petrópolis.

SILVEIRA, Luiz Carlos, 1996. Fundamentos de astronomia de posição e trigonometria esférica aplicada na determinação do Azimute Verdadeiro. Editora e livraria Luana Ltda. Criciúma. 